\title{
HUBUNGAN ANTARA NILAI TUGAS SEKOLAH (SCHOOL TASK'S VALUE) DENGAN MOTIVASI BELAJAR SISWA
}

\author{
Siti Ma'rifah Setiawati \\ Guru BK MTs Negeri III Surabaya \\ marifah0404@gmail.com
}

\begin{abstract}
ABSTRAK
Penelitian ini bertujuan untuk mengetahui hubungan antara nilai tugas sekolah (school task's value) dengan motivasi belajar siswa. Variabel variabel penelitiannya terdiri dari Nilai Tugas Sekolah dan Motivasi Belajar. Penelitian ini dilakukan pada 5 September 2015, sampel penelitian adalah siswa kelas VIII MTs Negeri III Surabaya yang terdiri dari 6 kelas. Teknik sampling yang digunakan pada penelitian ini adalah Random Sampling yang berjumlah 72 siswa dengan 12 siswa pada masing-masing kelas. Metode pengumpulan adalah dengan angket. Hasil analisis data untuk mengetahui korelasi antara Nilai Tugas Sekolah dengan Motivasi Belajar diperoleh dari $r=0,873$ dengan sig $=0,000(\operatorname{sig}<0,010)$ yang berarti ada korelasi atau ada hubungan yang sangat signifikan antara Nilai Tugas Sekolah dengan Motivasi Belajar. Untuk mengetahui besaran sumbangan variabel nilai tugas sekolah terhadap motivasi belajar adalah dengan melihat $r^{2}=0,762$ atau $76,2 \%$ variabel nilai tugas dapat mempengaruhi motivasi belajar.
\end{abstract}

Kata kunci : nilai tugas sekolah (school task's value), motivasi belajar siswa

PENDAHULUAN

Era globalisasi menuntut suatu bangsa untuk mampu melakukan kompetisi secara terbuka dengan negara-negara lain, jika ingin bertahan dalam tatanan kehidupan dunia. Dalam menghadapi kompetisi yang begitu tinggi, bangsa Indonesia harus memiliki SDM (sumber daya manusia) yang berkualitas. Sejarah menunjukkan beberapa faktor terpenting yang menentukan keberhasilan suatu bangsa adalah bukan karena kekayaan alam yang dimiliki, melainkan kualitas SDM yang dimiliki. Jika SDM lemah maka 
banyak peluang yang tidak dapat itu demi mencapai suatu tujuan. dimanfaatkan secara maksimal, Definisi dari motivasi belajar itu terlewatkan atau terbuang sia-sia. sendiri adalah kekuatan yang ada Upaya untuk mengembangkan SDM didalam diri seseorang yang dapat ini dapat dilakukan melalui proses menimbulkan kegiatan belajar untuk pendidikan yang memungkinkan mencapai suatu tujuan. Kesadaran berkembangnya manusia-manusia yang tentang pentingnya motivasi bagi berkualitas dan berpotensi.

Dalam upaya menjadi SDM yang berkualitas sehingga dapat berkompetisi, setiap siswa harus mencapai prestasi yang baik dan juga memiliki kualitas kepribadian yang baik pula. Prestasi yang tinggi tidak hanya ditentukan oleh faktor kecerdasan saja, namun motivasi juga menjadi penentu keberhasilan. Menurut Winkel (1991) dalam kegiatan belajar berlangsung, keberhasilannya bukan hanya ditentukan oleh faktor intelektual, akan tetapi juga faktor non intelektual, termasuk salah satunya motivasi.

Winkel (1991) mengatakan bahwa motivasi belajar adalah sebagai keseluruhan daya penggerak psikis didalam diri siswa yang menimbulkan kegiatan belajar, menjalin kelangsungan kegiatan belajar dan perubahan tingkah laku yang telah dimiliki sangat diperlukan, baik oleh para siswa maupun oleh para pendidik sendiri. Masalah motivasi belajar siswa dianggap sebagai masalah yang utama dalam pencapaian prestasi siswa disamping faktor-faktor yang lain.

Efektivitas belajar akan dapat ditingkatkan bila individu mempunyai motivasi, karena motivasi inilah yang memberi kekuatan dan arah pada perilaku yang ditampilkan individu. Motivasi sebagai faktor psikis yang berfungsi menimbulkan, mendasari dan mengarahkan perbuatan belajar. Motivasi dapat menentukan baik tidaknya dalam mencapai tujuan (Sardiman, 2001). Tanpa motivasi kegiatan belajar mengajar akan sulit untuk berhasil, karena seseorang akan berhasil dalam belajar kalau dalam dirinya ada keinginan untuk belajar.

memberikan arah pada kegiatan belajar 
Motivasi dapat menentukan (Kurikulum Berbasis Kompetensi). tingkat keberhasilan atau kegagalan Penerapan KBK (Kurikulum Berbasis perbuatan belajar siswa. Belajar tanpa Kompetensi) diharapkan siswa tidak disertai dengan adanya motivasi akan hanya memiliki pengetahuan, tetapi sulit untuk berhasil (Rusyan, 1989). juga ketrampilan (skill) serta sikap dan Siswa yang motivasi belajarnya rendah, nilai positif terhadap apa yang ada, tampak acuh tak acuh, mudah putus dengan menciptakan rasa suka dan asa, perhatiannya tidak tertuju pada pelajaran, akibatnya nilai atau prestasi yang dihasilkan juga rendah. Hal itu dapat dilihat ketika memasuki waktu ujian, para siswa hanya belajar pada malam hari saat besok ujian akan berlangsung, yang biasanya oleh para siswa disebut dengan SKS (Sistem Kebut Semalam) bahkan ada juga siswa yang menyontek, begitupun ketika mendapat tugas sekolah, para siswa akan mengerjakannya ketika mendekati deadline atau bahkan ada juga siswa yang tidak mengerjakannya. Ciri-ciri motivasi belajar rendah juga dapat dilihat ketika para siswa masuk sekolah sering terlambat dan tidak disiplin atau bahkan sampai sering membolos.

$$
\text { Peran motivasi dalam }
$$

menentukan keberhasilan siswa akan sangat penting ketika sekolah menetapkan kurikulum KBK suasana berpikir cerdas dalam proses belajar, sehingga siswa dapat berkembang dengan sempurna akal dan budinya.

Pendidikan kompetensi berarti bahwa ukuran ketercapaian hasil belajar adalah seberapa jauh kompetensi siswa. Diharapkan KBK dapat membekali peserta didik agar dapat menghadapi tantangan kehidupan secara mandiri, cerdas, kritis, rasional dan kreatif, KBK merupakan rencana pengaturan yang menekankan pada pengembangan kemampuan melakukan (kompetensi) tugas-tugas dengan standart performansi tertentu, sehingga hasilnya dapat dirasakan oleh peserta didik, berupa penguasaan terhadap seperangkat kompetensi yang disajikan di sekolah.

Dalam KBK proses belajar mengajar dengan siswa mandiri, sehingga siswa banyak mengerjakan 
tugas-tugas sekolah secara mandiri. sesuai dengan pendapat Kluckhohn Guru tidak hanya cukup memberikan (dalam Bahlil, 1981) yang mengatakan materi atau teori saja, tetapi guru bahwa nilai (value) merupakan memberikan latihan-latihan yang konsepsi yang secara eksplisit atau berupa tugas-tugas sekolah, tujuan implisit yang dapat membedakan diberikannya tugas-tugas sekolah individu maupun kelompok, karena tersebut adalah agar para siswa telah memberikan ciri khas yang baik mencapai kompetensi yang diinginkan. pada individu maupun kelompok.

Nilai yang dimiliki atau Seperti dikatakan Allport (dalam Bahlil, 1981) bahwa nilai (value) diyakini oleh setiap siswa itu berbedabeda, sehingga dengan adanya tugastugas sekolah tersebut tidak membuat semua siswa mempunyai nilai yang sama. Ada siswa yang mempunyai nilai negatif terhadap tugas sekolah yang diberikan oleh guru, siswa menganggap bahwa tugas sekolah merupakan beban dan menyita waktu. Sebaliknya, ada juga siswa yang mempunyai nilai positif, siswa menganggap bahwa tugas sekolah merupakan amanat dan kewajiban yang harus dikerjakan, agar dapat menambah wawasan, pengetahuan dan juga ketrampilan.

Pada dasarnya manusia memiliki konsep-konsep nilai dalam kepribadiannya. Nilai (value) merupakan aspek kepribadian, polapola perhatian dalam hidup, baik secara individu maupun kelompok. Hal ini merupakan pendukung sikap atau perbuatan yang dapat mengarahkan perilaku individu. Menurut pendapat Rokeach (dalam Bahlil, 1981) bahwa nilai (value) merupakan standart dan penguat bagi sikap dan tingkah laku, karena nilai sebagai keyakinan tunggal yang merupakan penentu bagi tingkah laku seseorang.

$$
\text { Perubahan-perubahan yang }
$$
terjadi pada masa transisi ini mencakup masa pubertas, meningkatnya tanggung jawab dan kemandirian yang berhubungan dengan menurunnya tingkat ketergantungan diri terhadap orang tua, perubahan suatu struktur kelas yang kecil menjadi lebih besar dan srtuktur sekolah yang lebih tidak personal, perubahan dari sistem satu guru menjadi banyak guru dan dari 
kelompok teman sebaya yang homogen dan kecil menjadi kelompok teman sebaya yang lebih besar dan heterogen, serta meningkatnya perhatian untuk mencapai prestasi dan unjuk kerja tertentu.

Hal-hal diatas juga melibatkan sejumlah sifat negatif dan menimbulkan stres, namun aspek dari transisi juga dapat bersifat positif. Siswa menjadi merasa lebih dewasa, memperoleh banyak mata pelajaran yang dapat dipilihnya, memiliki banyak kesempatan untuk menghabiskan lebih banyak waktu dengan teman sebaya dan untuk mendapatkan teman yang sesuai, menikmati rasa bebas dari pengawasan langsung orang tua, serta mungkin juga menjadi lebih tertantang secara intelektual dengan adanya tugastugas akademis. Santrock (2003) mengatakan bahwa pada masa remaja inilah individu membawa serangkaian nilai yang dapat mempengaruhi pikiran, perasaan dan tindakan individu.

Dari uraian diatas peneliti bermaksud untuk mengetahui hubungan antara nilai tugas sekolah (school task value ) bagi siswa dengan motivasi belajar siswa.

\section{METODE PENELITIAN}

Pada penelitian ini terdapat 2 (dua) variabel, yaitu :

Variabel Tergantung (Y) adalah

Motivasi Belajar

Variabel Bebas adalah Nilai Tugas

Sekolah

\section{Motivasi Belajar}

Motivasi belajar adalah dorongan yang ada pada diri individu, baik yang berasal dari dalam diri maupun dari luar diri individu, yang mengarahkan individu pada kegiatan atau proses belajar untuk mencapai tujuan yang diinginkan. Adapun ciriciri daripada motivasi belajar yang tinggi adalah : mempunyai minat terhadap tugas atau pekerjaan, tekun, ulet dan gigih dalam menghadapi kesulitan, memulai aktivitas dengan kemauannya sendiri, menyelesaikan tugas pada waktunya, mempergunakan umpan balik untuk menentukan tindakan yang lebih efektif guna tercapainya prestasi.

2. Nilai Tugas Sekolah 
Nilai tugas sekolah adalah Analisis yang digunakan dalam keyakinan dasar terhadap suatu penelitian ini adalah teknik analisis pekerjaan, kewajiban atau latihan- korelasi product moment dari Carl latihan yang dianggap berguna, Pearson untuk mengungkap hubungan berfungsi dan berharga, yang diberikan antara Nilai Tugas Sekolah dengan oleh guru ketika berada di sekolah, Motivasi Belajar. Analisis data dalam baik yang dikerjakan di sekolah penelitian ini menggunakan SPSS maupun yang dikerjakan di rumah. (Statistic program for Social Science) Adapun komponen daripada nilai tugas for Windows realease 21,0.

sekolah adalah : ketertarikan terhadap tugas, pentingnya tugas bagi individu, kegunaan tugas bagi individu.

Penelitian ini dilakukan pada 5 September 2015, sampel penelitian adalah siswa kelas VIII MTs Negeri III Surabaya yang terdiri dari 6 kelas. Teknik sampling yang digunakan pada penelitian ini adalah Random Sampling yang berjumlah 72 siswa dengan 12 siswa pada masing-masing kelas.

Hasil analisis data untuk mengetahui korelasi antara Nilai Tugas Sekolah dengan Motivasi Belajar diperoleh dari $\mathrm{r}=0,873$ dengan $\operatorname{sig}=$ $0,000$ ( $\operatorname{sig}<0,010)$ yang berarti ada korelasi atau ada hubungan yang sangat signifikan antara Nilai Tugas Sekolah dengan Motivasi Belajar. Untuk mengetahui besaran sumbangan variabel nilai tugas sekolah terhadap motivasi belajar adalah dengan melihat

Metode pengumpulan data dalam penelitian ilmiah merupakan aspek yang penting untuk diperhatikan, karena penggunaannya sangat menentukan perolehan data-data yang relevan dan akurat, metode pengumpulan data yang dipergunakan dalam penelitian ini adalah angket.

HASIL PENELITIAN $r^{2}=0,762$ atau $76,2 \%$ variabel nilai tugas dapat mempengaruhi motivasi belajar.

\section{PEMBAHASAN}

Analisis terhadap hasil penelitian ini secara kuantitatif menunjukkan bahwa terdapat hubungan yang sangat signifikan antara variabel Nilai Tugas Sekolah dengan 
variabel Motivasi Belajar. Hasil ini mendukung hipotesis yang telah diajukan, yaitu ada hubungan antara Nilai Tugas Sekolah dengan Motivasi Belajar siswa, dimana koefisien korelasi kedua variabel penelitian diperoleh nilai $\mathrm{r}=0,873$ dengan $\operatorname{sig}=$ 0,000 (sig < 0,010).

Hasil penelitian ini sesuai dengan pendapat yang dikemukakan oleh Gage dan Berliner (dalam Winkel, 1991) ada beberapa faktor yang dapat mempengaruhi motivasi dalam belajar, salah satunya adalah nilai. Begitu pula dengan adanya nilai yang dimiliki oleh siswa dapat memberinya kekuatan atau dorongan untuk mencapai tujuantujuan atau harapannya, yaitu memberinya motivasi dalam belajar untuk mencapai prestasi yang diinginkan, hal ini sesuai dengan pendapat dari Adisubroto (dalam Dayakisni dan Yuniardi, 2004) yang mengatakan bahwa nilai memiliki komponen motivasional yang kuat, artinya nilai berfungsi motivasional, seperti halnya komponen kognitif, afektif dan behavioral dan juga sesuai dengan pendapat Maryani dan Farida (dalam Antropologi, 1997) nilai adalah sesuatu yang dianggap berguna, berfungsi dan berharga. Tim Sosiologi (dalam Sosiologi, 2005) juga mengatakan bahwa salah satu fungsi nilai adalah sebagai faktor pendorong, hal ini berkaitan dengan nilai-nilai yang berhubungan dengan cita-cita atau harapan, sehingga siswa yang mempunyai keyakinan bahwa tugas sekolah adalah penting dan menganggap bahwa tugas sekolah yang diberikan kepadanya merupakan sesuatu yang berguna, berfungsi dan berharga, maka siswa tersebut akan menjadi semangat atau termotivasi untuk belajar sehingga mendapatkan hasil akademik atau prestasi yang baik sesuai dengan harapannya.

Salah satu konteks yang penting dalam proses belajar adalah sekolah, banyak orang berpendapat bahwa sekolah adalah suatu tempat dimana proses belajar secara akademis mendominasi, tetapi sekolah sebenarnya lebih dari sekedar kelas akademis dimana siswa dapat berpikir, melakukan penalaran dan mengingat. Akan tetapi sekolah juga merupakan suatu arena sosial yang penting bagi remaja. 
Tugas akademik merupakan dalam merespon atau menanggapi tugas yang harus di selesaikan oleh tugas-tugas sekolah yang banyak semua siswa untuk memenuhi diberikan kepadanya. Hal ini karena kurikulum yang ada. Sekolah telah nilai merupakan keyakinan dasar atau menerapkan KBK (Kurikulum Berbasis kumpulan sikap yang abstrak tentang Kompetensi) yang mana dalam apa yang benar dan penting yang program KBK tersebut siswa banyak dianggap berguna, berfungsi dan mendapatkan latihan-latihan atau berharga, oleh karena itu nilai akan tugas-tugas sekolah, baik tugas-tugas memberi energi dan mengarahkan yang harus dikerjakan disekolah aktivitas individu kearah tujuan-tujuan maupun tugas-tugas yang harus tertentu (Winkel, 1991). Tim Sosiologi dikerjakan dirumah. dimana tugas- (dalam Sosiologi, 2005) juga tugas yang diberikan kepada siswa mengatakan bahwa salah satu fungsi tersebut bertujuan untuk meningkatkan nilai adalah sebagai faktor pendorong, kompetensi para siswa.

Sebelum siswa masuk ke dunia pendidikan (sekolah), siswa telah membawa sistem nilai, dan nilai sistem yang dimiliki tersebut dibentuk dari pola asuh orang tua, pola asuh yang diterapkan oleh masing-masing orang tua pastilah berbeda, sehingga hal itu juga yang menyebabkan nilai yang dimiliki oleh siswa tersebut dapat berbeda-beda. Nilai-nilai yang ada pada siswa dapat terjadi perubahan sesuai dengan perkembangan siswa itu sendiri.

hal ini berkaitan dengan nilai-nilai yang berhubungan dengan cita-cita atau harapan.

Jadi siswa yang mempunyai keyakinan bahwa tugas sekolah adalah penting dan menganggap bahwa tugas sekolah yang diberikan kepadanya merupakan sesuatu yang berguna, berfungsi dan berharga, maka siswa tersebut akan menjadi semangat atau termotivasi untuk belajar sehingga mendapatkan hasil akademik atau prestasi yang baik sesuai dengan harapannya.

\section{KESIMPULAN}

Adanya nilai yang dimiliki tersebut dapat mempengaruhi siswa 
Berdasarkan hasil penelitian dan pembahasan yang telah dilakukan, maka didapat suatu kesimpulan bahwa ada hubungan yang sangat signifikan antara nilai tugas sekolah dengan motivasi belajar siswa, sehingga semakin baik nilai atau keyakinan yang dimiliki oleh siswa terhadap tugas sekolah, maka akan semakin baik pula motivasi belajarnya. Demikian pula sebaliknya, semakin buruk nilai atau keyakinan yang dimiliki oleh siswa terhadap tugas sekolah, maka akan semakin rendah pula motivasi belajar yang dimilikinya.

\section{SARAN}

Berdasarkan hasil penelitian dan pembahasan yang telah dilakukan, maka penulis dapat memberikan saran antara lain :

a) Bagi pendidik (guru) agar dapat memberikan tugas sekolah yang dapat lebih memotivasi belajar siswa, sehingga prestasi yang telah dicapai dapat dipertahankan atau lebih ditingkatkan lagi.

b) Bagi siswa agar dapat mempertahankan nilai yang telah dimiliki terhadap tugas sekolah serta motivasi belajarnya dapat tetap dipertahankan, sehingga prestasi yang telah dicapai dapat lebih ditingkatkan lagi.

\section{DAFTAR PUSTAKA}

Abror, R. 1993. Psikologi Pendidikan. Yogyakarta. PT. Tiara Wacana.

Ahmadi, A. 1991. Teknik Belajaryang Efektif. Jakarta. Rineka Cipta.

Ancok, J. 1992. Teknik Penyusunan Skala Pengukuran. Yogyakarta. Pusat

Azwar, S. 2005. Penyusunan Skala Psikologi. Yogyakarta. Pustaka Pelajar. Penelitian Kependudukan. Universitas Gadjah Mada.

Bahlil. 1981. Sikap Orang Jawa Terhadap Nilai-nilai Hidup, Serta Ciri-ciri Kepribadian. Yogyakarta. Universitas Gadjah Mada.

Davies, I.K. 1986. Pengelolaan Belajar. Jakarta. Rajawali.

Dayakisni, T \& Yuniardi, S. 2004. Psikologi Lintas Budaya. Malang. UMM Press.

Depdiknas. 2002. Kamus Besar Bahasa Indonesia. Jakarta. Balai Pustaka.

Depdiknas. 2004. Kamus Pelajar Sekolah Lanjutan Tingkat Atas. Jakarta. Pusat Bahasa Depdiknas. 
Hurlock. 2002. Psikologi Nicke. 2000. Hubungan Persepsi Siswa Perkembangan. Jakarta. Terhadap Metode Pengajaran Erlangga. dengan Motivasi Belajar. Skripsi. Universitas Surabaya.

Hutabarat, E.P. 1995. Cara Belajar. Jakarta. Bpk Gunung Mulia.

Roediger, etc. 1984. Psychology. Boston. Little, Brown\&Company.

Kaswardi. 2000. Pendidikan Nilai

Memasuki Tahun 2000. Jakarta. Grasindo.

Robbins, P.S. 2002. Perilaku Organisasi. Jakarta. PT. Koeswara, E. 1991. Teori-teori Kepribadian. Bandung. Eresco.

Maryani, E. \& Farida, N. 1997. Antropologi. Bandung. PT. Grafindo Media Pratama. Prenhallindo.

Rohani, A \& Ahmadi. 1991. Pengelolaan Pengajaran. Jakarta. Rineka Cipta.

Rusyan, T, dkk. 1989. Pendekatan dalam Proses Belajar mengajar. Bandung. CV. Remadja Karya.

Salim, P \& Salim, Y. 1991. Kamus Bahasa Indonesia Kontemporer. Jakarta. Modern English Press.

Santrock, J.W. 2003. Adolescence; Perkembangan Remaja. Jakarta. Erlangga.

Sardiman, A.M. 1992. Interaksi dan Motivasi Belajar Mengajar. Jakarta. Rajawali Pers.

Sarwadi dan Lamijan. 1992. Teori Belajar Implementasi dalam Proses Belajar Mengajar. Surabaya. Uni Pres.

Soekanto. 1997. Sosiologi Suatu Pengantar. Jakarta. PT. Raja Grafindo Persada.

Soemanto, W. 1998. Psikologi Pendidikan. Jakarta. PT. Rineka 
Cipta.Suryabrata, S. 1984.

Psikologi Pendidikan. Jakarta.

CV. Rajawali.

Syah, M. 1995. Psikologi Pendidikan.

Bandung. Remaja Rosdakarya.

Tadjab. 1994. Ilmu Jiwa Pendidikan. Surabaya. Karya Abditama.

Tim Sosiologi. 2005. Sosiologi, Suatu

Kajian Kehidupan Masyarakat. Yudhistira.

Wigfield, A, etc. 1997. Journal of Educational Psychology.

Winkel, W.S. 1991. Psikologi Pengajaran. Jakarta. PT. Gramedia. 
